\title{
Urban-planning analysis of the project of infill development in terms of sustainable development of the city
}

\author{
Ekaterina Popova ${ }^{1, *}$, and Irina Ptuhina ${ }^{1}$ \\ ${ }^{1}$ Peter the Great St. Petersburg Polytechnic University, St. Petersburg, Russian Federation
}

\begin{abstract}
This study is devoted to two pressing problems of Russian urban development: infill development and sustainable development of territories. The authors put forward the concept of assessing effectiveness of land usage, based on urban-planning standards, which is substantiated relationship between planning parameters and sustainable development of the city. The authors also considered the project of residential infill development, and proposed alternative options for planning solutions that are more consistent with current regulations.
\end{abstract}

\section{Introduction}

The modern city is a complex organism that unites many people with access to a complex of goods. According to the World Health Organization, in 2015, 54\% of the world's population lived in cities, and the projected urban population growth from 2015 to 2020 was estimated at $1.84 \%$ per year [1]. Such high rate of urbanization was recorded for the first time in the history of mankind.

The rapid growth of cities has many serious consequences - environmental, economic and social. The concept of sustainable urban development was proposed in 2012, during the UN Conference in Rio de Janeiro [2]. Initially, this concept reflected only the environmental aspect: reducing emissions into the environment, monitoring the quality of water and air, and waste treatment programs. However, over time, the concept of "sustainable development" began to be applied also to the social and economic spheres.

A large number of studies $[3,4,5]$ indicate a significant impact of the construction industry on the environmental situation in cities. However, at the same time, construction is one of the main sectors of the urban economy, using the most valuable resource of the city - free territories. Poor urban development leads to the deterioration of transport, and then to the degradation of environmental situations. Also, according to studies, the quality of the urban environment affects the social sphere $[6,7,8]$. Thus, we can conclude that rational land use is an important aspect of sustainable urban development.

However, in Russia, the land use management system is not perfect. The problems of building regulation combined with the lack of a comprehensive pre-project analysis of the

\footnotetext{
${ }^{*}$ Corresponding author: pmkate1210@mail.ru
} 
territory affected the quality of the urban environment. This problem is being actively studied by Russian researchers [9, 10].

Along with the imperfection of urban planning legislation, a serious obstacle to the development of urban environment is a lack of proper regulation in relations between investors and municipalities [11]. Today, implementation of all stages of construction, including laying of communications to the site and construction of roads, is a responsibility of the investor. As a result, in most Russian cities there is a problem of infill development, when investors build up by single multi-storey residential buildings small vacant plots of land in dense urban environment. As a result, it leads to degradation of the urban environment, increasing burden on existing social and transport infrastructure. Also often a situation occurs when an investor erects a residential complex in the suburbs, but does not provide future residents with necessary social and transport infrastructure. The quality of living environment also suffers, and correction of the situation is a burden on local municipality. A comprehensive development of territories may become a solution to the problem. However, this type of public-private partnership in construction is still not sufficiently regulated. Researchers suggest ways to solve this problem [12, 13], but they are based on legislative regulation, which requires a long development of bills, with their subsequent consideration and approval. It is necessary to find a more convenient and quick solution.

The search for a compromise between the interests of investors, citizens and the municipality became the topic of this study. In this article, authors provide an analysis of compliance of residential building project with the urban planning standards of St. Petersburg and the Russian Federation, as well as assess effectiveness of land usage. According to the results of analysis, authors give alternative options for planning decisions and evaluate the effectiveness of usage of the land plot for development for each of the options.

An example of a sealing development in St. Petersburg was taken as a case: the project of elite residential complex "Legenda" on Institutsky Prospekt 16. This project of a highrise residential complex is being implemented in the existing residential area, and upon completion, it will potentially have a significant negative impact on existing transport, social and recreational infrastructure.

\section{Materials and Methods}

Research based on set of urban-planning standards of Russia and St. Petersburg. Urbanplanning standards were created for providing of high quality of urban space. This complex of documentation takes in account social, labor, leisure and domestic needs of people. Next set of tables contains main factors and special units, which were used in calculations.

Table 1 includes main urban factors of effectiveness for plots usage - building factor (equal to ratio of area of the build-up area to area of the plot) and coefficient of density (equal to ratio of the common area of all above-ground floors to area of the plot). Also table contains recommended living area per person for residential buildings of business class, this data were taken according SP 42.13330.2011 "Town planning". Parameters for parking are regulated by the Rules of land use and development of St. Petersburg.

Table 1. Regulatory Indicators.

\begin{tabular}{|c|c|}
\hline Regulatory building factor (S building / S plot) & 0,4 \\
\hline Regulatory coefficient of density of building (S build above ground / S plot) & 1,2 \\
\hline Living area per person for business class, $\mathrm{m}^{2}$ /person & 40 \\
\hline Minimum area of parking space with driveways, $\mathrm{m}^{2}$ & 25 \\
\hline
\end{tabular}




\begin{tabular}{|c|c|}
\hline Minimum specific number of parking spaces, parking space per $80 \mathrm{~m}^{2}$ of apartments & 1 \\
\hline Minimum percentage of parking spaces in the open area, $\%$ & 25 \\
\hline
\end{tabular}

Table 2 contains specific dimensions of adjoined sites, according SP 42.13330.2010, Table 2. These parameters equal minimal area per person, and regulate sizes of places for rest and domestic needs.

Table 2. Specific dimensions of sites.

\begin{tabular}{|c|c|}
\hline Children's playground, m2/person & 0,7 \\
\hline Recreation areas for adults, m2/person & 0,1 \\
\hline Sport fields, m2/person & 2 \\
\hline Area for litter containers and dog walking, m2/person & 0,3 \\
\hline Landscaping area, $\mathrm{m} 2 / 100 \mathrm{~m} 2$ of apartments & 23 \\
\hline
\end{tabular}

Territory of any house includes building spot, adjoined site and technical and fire passages. Table 3 contains general parameters of fire passes from SP 4.13130.2013 Systems of fire protection. Restriction of fire spread at object of defense.

Table 3. Parameters of fire passages.

\begin{tabular}{|c|c|}
\hline Width of pass, if height of building from $13 \mathrm{~m}$ to $46 \mathrm{~m}, \mathrm{~m}$ & 4,2 \\
\hline Width of pass, if height of building more than $46 \mathrm{~m}, \mathrm{~m}$ & 6 \\
\hline $\begin{array}{c}\text { Minimum space between wall of building and border of pass (if height of building is } \\
\text { less than } 28 \mathrm{~m} \text { ), } \mathrm{m}\end{array}$ & 5 \\
\hline $\begin{array}{c}\text { Minimum space between wall of building and border of pass (if height of building is } \\
\text { more than } 28 \mathrm{~m} \text { ), } \mathrm{m}\end{array}$ & 8 \\
\hline
\end{tabular}

If building is higher than $28 \mathrm{~m}$, the fire passage must be organized on two longitudinal sides. Figure 1 shows configuration of passage, which was chosen for building layout according set of rules. For further calculations, a minimum area of fire passages is used, including travel along the perimeter of the building. The distance from main facade to the Likhachev alley is unknown; therefore it is impossible to find out the full area of passages.

Likhachev alley

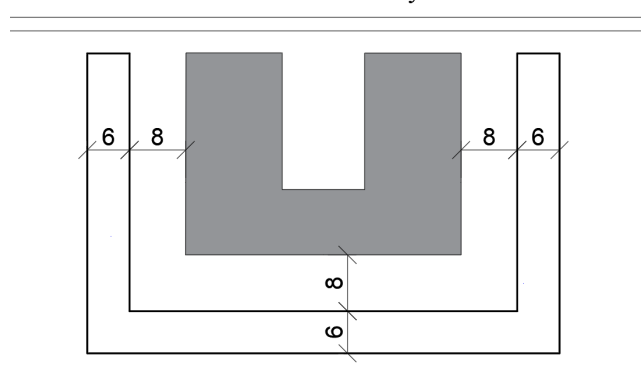

Fig. 1. Configuration of fire passage (in meters).

Task of analysis is to compare area of the building plot with standard dimensions of adjoining sites required for a building of such height.

Table 4 includes constant parameters of model. It was taken from project documentation, published on official web-site [14], from public cadastre map [15], from the Rules of land use and development of St. Petersburg, and from set of rules 54.13330.2016 "Multicompartment residential buildings". 
Table 4. Constant parameters of model.

\begin{tabular}{|c|c|}
\hline Area of Land Plot, $\mathrm{m} 2$ & 6305 \\
\hline Type of Usage & TZZh2 \\
\hline Floor height, $m$ & 3,3 \\
\hline
\end{tabular}

\section{Results}

Table 5 presents the main parameters of the original project and alternatives, as well as the associated regulatory dimensions of the house adjoining sites.

Column "Existing project" contains all data about project of residential complex "Legenda". Building factor of this project (equals 0.14 ) is less then normative (equals 0.4), but coefficient of density (equals 2.83 ) is much more than normative (equals 1.2). It means that footprint of building can be bigger, but height is too huge for this plot.

Column "Project in the same building spot" contains fixed parameters of height - there are less floors, and one type (with biggest flats) not used. In this case, coefficient of density (equals 1.13) is less than normative (equals 1.2), but footprint still too small.

Third column, "Project, matching to normative factors" contains new concept of building. These parameters were taken by multiplying area of plot on normal factors from table 1. Also data from table used for understanding general number of residents.

Part of table "Regulatory area of adjoining sites excluding fire and technical passages,

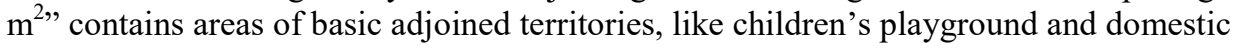
area. This data was taking by multiplying of number residents on factors from table 2 .

Bottom part of table contains resulting areas of three components of plot - build-up area, adjoined sites and fire passages. Sizes of passages changed according height of the building. Graphically results of this comparison are shown on figures 2 and 3.

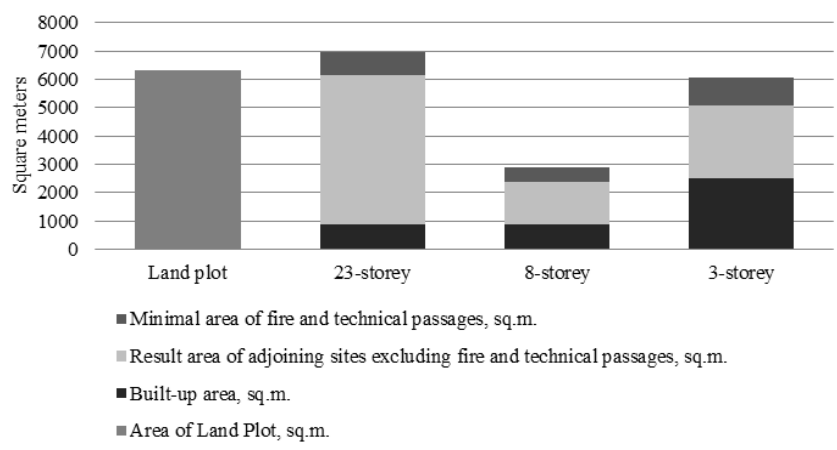

Fig. 2. Comparison of areas of house territories with different parameters of building.

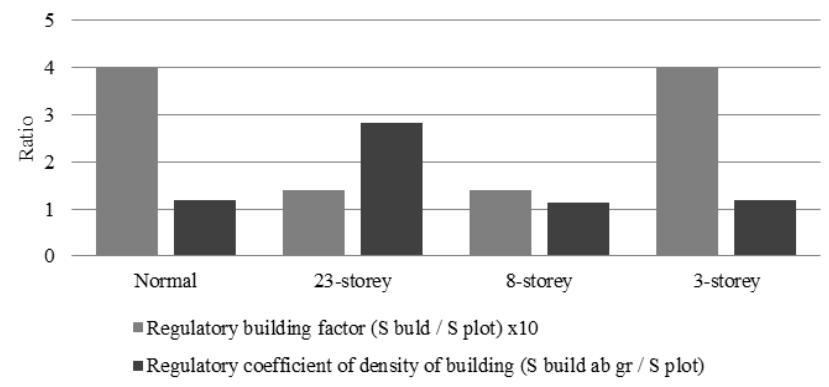

Fig. 3. Comparison of regulatory factors of projects with different parameters. 
Table 5. Modeling of variants of residential complex.

\begin{tabular}{|c|c|c|c|c|c|c|c|}
\hline & \multicolumn{3}{|c|}{ Existing project } & \multicolumn{3}{|c|}{$\begin{array}{l}\text { Project in the same } \\
\text { building spot }\end{array}$} & $\begin{array}{c}\text { Project, } \\
\text { matching } t \\
\text { normative } \\
\text { factors }\end{array}$ \\
\hline Built-up area, $\mathrm{m}^{2}$ & \multicolumn{3}{|c|}{893} & \multicolumn{3}{|c|}{893} & 2522 \\
\hline $\begin{array}{l}\text { General } \\
\text { Storeys }\end{array}$ & \multicolumn{3}{|c|}{23} & \multicolumn{3}{|c|}{8} & 3 \\
\hline $\begin{array}{l}\text { Non-residential } \\
\text { storeys }\end{array}$ & \multicolumn{3}{|c|}{5} & \multicolumn{3}{|c|}{3} & 0 \\
\hline $\begin{array}{l}\text { Height of the } \\
\text { building, } m\end{array}$ & \multicolumn{3}{|c|}{68,8} & \multicolumn{3}{|c|}{16,5} & 9,9 \\
\hline & Per unit & Count & Sum & Per unit & Count & Sum & \\
\hline $\begin{array}{l}\text { Area of floor } \\
\text { Type } 1, \mathrm{~m}^{2}\end{array}$ & 803,3 & 5 & 4016,45 & 803,3 & 2 & 1606,58 & \\
\hline $\begin{array}{l}\text { Residents } \\
\text { Type } 1\end{array}$ & 15 & & 75 & 15 & & 30 & \\
\hline $\begin{array}{l}\text { Area of floor } \\
\text { Type } 2, \mathrm{~m}^{2}\end{array}$ & 803,4 & 6 & 4820,52 & 803,4 & 2 & 1606,84 & \\
\hline $\begin{array}{l}\text { Residents } \\
\text { Type } 2\end{array}$ & 16 & & 96 & 16 & & 32 & \\
\hline $\begin{array}{c}\text { Area floor Type } \\
3, \mathrm{~m}^{2}\end{array}$ & 803,5 & 5 & 4017,65 & 803,5 & 1 & 803,53 & \\
\hline $\begin{array}{c}\text { Residents } \\
\text { Type } 3\end{array}$ & 16 & & 80 & 16 & & 16 & \\
\hline $\begin{array}{l}\text { Area of floor } \\
\text { Type } 4, \mathrm{~m}^{2}\end{array}$ & 808,7 & 2 & 1617,44 & 808,7 & 0 & 0 & \\
\hline $\begin{array}{l}\text { Residents } \\
\text { Type } 4\end{array}$ & 11 & & 22 & 11 & & 0 & \\
\hline $\begin{array}{l}\text { Number of } \\
\text { residents }\end{array}$ & \multicolumn{3}{|c|}{273} & \multicolumn{3}{|c|}{78} & 166 \\
\hline $\begin{array}{l}\text { General area of } \\
\text { flats, } \mathrm{m}^{2}\end{array}$ & \multicolumn{3}{|c|}{14472} & \multicolumn{3}{|c|}{4017} & 6658,08 \\
\hline $\begin{array}{c}\text { Area of building } \\
\text { above ground, } \\
\mathrm{m}^{2}\end{array}$ & \multicolumn{3}{|c|}{17860} & \multicolumn{3}{|c|}{7144} & 7566 \\
\hline $\begin{array}{c}\text { Number of } \\
\text { parking spaces }\end{array}$ & \multicolumn{3}{|c|}{171} & \multicolumn{3}{|c|}{51} & 84 \\
\hline \multicolumn{8}{|c|}{ Regulatory indicators of construction } \\
\hline Building factor & \multicolumn{3}{|c|}{0,14} & \multicolumn{3}{|c|}{0,14} & 0,4 \\
\hline $\begin{array}{l}\text { Factor of density } \\
\text { of building }\end{array}$ & \multicolumn{3}{|c|}{2,83} & & 1,13 & & 1,2 \\
\hline & Regulator & rea of ad & ing sites e & ding fire & technic & assages, $\mathrm{m}$ & \\
\hline $\begin{array}{c}\text { Children's } \\
\text { playground }\end{array}$ & & 191,1 & & & 54,6 & & 116,2 \\
\hline Recreation & & 27,3 & & & 7,8 & & 16,6 \\
\hline Sport fields & & 546 & & & 156 & & 332 \\
\hline Domestic areas & & 81,9 & & & 23,4 & & 49,8 \\
\hline Landscaping & & 3329 & & & 924 & & 1531 \\
\hline $\begin{array}{c}\text { Uncovered } \\
\text { parking }\end{array}$ & & 1068,7 & & & 318,7 & & 525,000 \\
\hline $\begin{array}{l}\text { Result area of } \\
\text { adjoining sites, } \\
\mathrm{m}^{2}\end{array}$ & & 5243,6 & & & 1484,4 & & 2570,958 \\
\hline $\begin{array}{c}\text { Plot area } \\
\text { excluding } \\
\text { building spot, } \mathrm{m}^{2}\end{array}$ & & 5412 & & & 5412 & & 3783 \\
\hline $\begin{array}{c}\text { Area of fire } \\
\text { passages, } \mathrm{m}^{2}\end{array}$ & & 842 & & & 524 & & 993 \\
\hline
\end{tabular}




\section{Discussion}

\subsection{Interpretation of results}

A comparison of the two graphs shows that the maximum efficiency of land use is achieved during the construction of a 3-storey residential building with a built-up area of $2522 \mathrm{~m} 2$. For this project, all the requirements for the planning of the territory are feasible; the land is used as efficiently as possible.

The compliance of the low-rise building option with the principles of sustainable development of territories follows from the following characteristics. According to studies in the field of environmental sustainability of buildings, multi-story buildings have a significant negative impact on the living environment [16]. According to another study, high-rise buildings consume $25 \%$ more energy than low-rise buildings [17]. This suggests that low-rise residential buildings are more environmentally sustainable than high-rise residential buildings.

It is also important to evaluate the impact of the future building on the existing living environment. According to the calculations presented in the article, the possible number of residents of a 3-storey building is not critical for the existing infrastructure of the district.

Thus, we can conclude that the project of a low-rise apartment building, corresponding to urban planning regulations, is a more preferable option from the point of view of sustainable development of the urban environment.

\subsection{Comparison with other researches}

Consider examples of other analytical studies on urban development.

The article "Management of territory development based on an integrated assessment" discusses the methodology of multi-component assessment of the urban environment using GIS technologies, and the results are used to make planning decisions [18]. This approach provides interesting opportunities for the implementation of the principles of sustainable development.

The article "Mathematical and cartographic modeling of urban environment development" describes a methodology for assessing the development density of a residential area using the ArcGIS tool and spatial databases [19]. The results of the application of this technique allow us to assess the urban development situation and make a decision on the way for the further development of the territory.

The article "Mapping and evaluating urban density patterns in Moscow, Russia" presents the results of the analysis of the density of the urban environment on the example of Moscow using GIS technologies [20]. Researchers classified the territory of the city by type of use (residential, agricultural, forestry, etc.) and analyzed the changes in their borders from 1995 to 2016 . The results allowed analyzing the density of settlement and evaluating the changes caused by the uncontrolled growth of urban boundaries. Similar methods are also important for setting sustainable development goals.

All the above studies are united by an analysis of the already existing urban environment. The results can be used by municipalities to adjust urban planning policies, but this does not affect the development of individual development projects. The methodology described in this article offers solutions for optimizing indicators at the predesign stage, in order to reduce the negative impact of point and quarter development. 


\subsection{Ways of development of the study}

The main development path of this study is its complication due to the inclusion of new indicators of sustainable development in the analysis.

It is also important to evaluate the economic aspect of the territory development project - strategies for creating a comfortable environment will not be successful if they prove to be economically disadvantageous.

Of particular research interest is the development of the application of this analysis to integrated development projects. This direction in Russian housing construction is gradually gaining popularity, however, investors are faced with a number of difficulties for example, modeling the development parameters of the territory, assessing the investment attractiveness of projects and determining the shares of private and state financing.

\section{Conclusion}

The relevance of urban development issues in Russia is obvious, but scientific basis for this topic is not well developed. This is partly due to the fact that research requires an interdisciplinary approach, partly due to the lack of practical development and design decisions by scientific justification. In this case, works that offer practical solutions, based on theoretical research, become especially relevant.

Modeling the development of territories on the basis of the principles of sustainable development, followed by an economic analysis of the proposed models, can fundamentally change the urban planning policy in Russia and bring the quality of the urban environment to a new level.

\section{References}

1. Urban population growth - Global Health Observatory (GHO) data, World Health Organization, https://www.who.int/gho/urban health/situation trends/urban population growth/en/ last accessed at 2019/07/07.

2. Sustainable development goal 11 - Make cities and human settlements inclusive, safe, resilient and sustainable. Sustainable development goals knowledge platform https://sustainabledevelopment.un.org/sdg11 last accessed at 2019/07/07.

3. S.O. Ametepey, S.K. Ansah, Impacts of Construction Activities on the Environment: The Case of Ghana [Electronic version]. J. of Envir. and Ear. Scie., 5, № 3, 18-26 (2015)

4. Construction's Impact on the Environment, Construction News, Sourceable https://sourceable.net/constructions-impact-on-the-environment/, last accessed at 2019/07/10

5. M.D. Kashin, T.B. Nabokova, V.N. Bgashev, Ecological Interaction of Tall Buildings and Environment. Ex. of For. Count. Arch. and Mod. Inf. Tech., 1 (30), 1-8 (2015)

6. R. Sairinen, Social impact assessment in urban planning. The Sustainable City III, 423430 (2004)

7. E. Miller, L. Buys, Making a Case for Social Impact Assessment in Urban Development: Social Impacts and Legal Disputes in Queensland. Proc. Soc. and Behav. Scie., 65, 285-292 (2012) 
8. Urban Threats (n.d.) - National Geographic https://www.nationalgeographic.com/environment/habitats/urban-threats/, last accessed at $2019 / 07 / 10$

9. L.Ya. Gertsberg, Actualization of the Methodological Basis of Developing General Plans in the Context of Modern Threats and Challenges to Urban Development (Acad. Arch. and Const., (2), 91-97, 2018) DOI 10.22337/2077-9038-2018-2-91-97

10. Al. Gushchin, F. Gushchin, S. Sanok, Analysis of the Urban Fabric Using Land Use and Development Rules. Mod. Appl. Scie., 9, No 5. 50-62 (2015) DOI:10.5539/mas.v9n5p50.

11. P.N. Kostrikin, Problems o efficiency of realization of state (municipal) housing renovation problems. Vestnik MGSU, 12 (11 (110)), 1221-1228 (2017) DOI:10.22227/1997-0935.2017.11.1221-1228

12. O.A. Dement'eva, Legal mechanisms of interaction of public authorities and local governments with economic operators in the investment sphere in the context of capital investments (J. of Russ. Law, 7 (223)), 121-130, 2015) DOI: 10.12737/11761

13. P.N. Kostrikin, Model of synchronization of integrated development of multifunctional urban environment. Vestnik MGSU, 13 (3 (114)), 339-348 (2018) DOI:10.22227/1997-0935.2018.3.339-348

14. Legenda na Institutskom, https://institutsky16.legenda-dom.ru, last accessed 2018/12/20.

15. Public cadastre map of St. Pet., http://roscadastr.com/map/sankt-peterburg last accessed at 2019/08/10.

16. B. Giyasov, I. Giyasova, The Impact of High-Rise Buildings on the Living Environment. E3S Web of Conf., 33, High Rise Const., 01045 (2018). DOI: https://doi.org/10.1051/e3sconf/20183301045.

17. P. Du, A. Wood, B. Stephens, X. Song, Life-Cycle Energy Implications of Downtown High-Rise vs. Suburban Low-Rise Living: An Overview and Quantitative Case Study for Chicago. Buildings, 5, 1003-1024 (2015) DOI: 10.3390/buildings5031003.

18. S. Sheina, W. Dietmar, R. Matveyko, L. Teryukova, Management of territory development based on an integrated assessment. Eur. Scie. rev, (11-12), 214-219 (2015)

19. K.P. Makarova, Yu.S. Levina, O.A. Zarubin, A.E. Klimov, Mathematical and cartographic modeling of the urban development density. Scie. and Tech. Bul. of the Bryansk St. Un., 3, 321-327 (2018) DOI: 10.22281/2413-9920-2018-04-03-321-327

20. K. Choudhary, M.S. Boori, A.V. Kupriyanov, Mapping and evaluating urban density patterns in Moscow. Comp. opt., 41 (4), 528-534 (2017) DOI: 10.18287/2412-61792017-41-4-528-534 